\title{
PENGARUH PENDAPATAN ORANG TUA TERHADAP MOTIVASI KULIAH MAHASISWA JURUSAN SOSIOLOGI ANGAKATAN 2016-2019 FAKULTAS ILMU SOSIAL UNIVERSITAS NEGERI MALANG
}

\author{
Rusmiatul Ulya $^{1}$, Ajeng Ima Sukmawati ${ }^{2}$, Annisa Titnia ${ }^{3}$, Nadya Bherta Viana Putri ${ }^{4}$, Rendi Kurnia

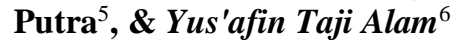 \\ 1,2,3,4,5,6 Fakultas Ilmu Sosial, Universitas Negeri Malang \\ Email: rusmiatul.ulya06@gmail.com, ajengima79@gmail.com, annisatitania@gmail.com, \\ nadyabherta14@gmail.com, rendiputra03@gmail.com,afintaji@gmail.com
}

\section{INFO ARTIKEL}

Riwayat Artikel:

Menerima : 30 Nopember 2019

Revisi : 17 April 2020

Diterima : 26 April 2020

\section{Kata Kunci:}

Pendapatan orang tua, motivasi kuliah, pembagian kelas

Keywords:

Parents' income, motivation in learning, class division

\section{Korespondensi:}

Rusmiatul Ulya

Fakultas Ilmu Sosial, Universitas

Negeri Malang

Email:

rusmiatul.ulya06@gmail.com

\section{ABSTRAK}

Mahasiswa jurusan Soiologi angkatan 2016 - 2019 Fakultas Ilmu Sosial Universitas Negeri Malang mendapatkan pembagian golongan UKT. Artikel ini bertujuan untuk memaparkan hasil penelitian yang menunjukkan bahwa pembayaran UKT dipengaruhi oleh pendapatan orang tua sehingga dapat mengukur motivasi kuliah mahasiswa dalam pembelajaran pada taraf rendah, sedang, atau tinggi. Metode yang digunakan yaitu dengan pendekatan kuantitatif dan teknik pengumpulan datanya menggunakan accidental sampling dengan jumlah responden sebanyak 72 orang dari populasi sejumlah 345 mahasiswa. Hasil dari penelitian ini yaitu $\mathrm{H}_{0}$ diterima yang menyatakan bahwa tidak terdapat pengaruh antara pendapatan orang tua terhadap motivasi kuliah dengan nilai koefisien korelasi uji pearson product moment - 0,94. Faktor faktor yang mempengaruhi hal yang lain dari penemuan data dengan penghitungan taraf signifikansinya variabel X (pendapatan orang tua) terhadap variabel Y (motivasi kuliah) sejumlah $1 \%$ dan sisanya $99 \%$ variabel $\mathrm{X}$ (pendapatan orang tua) mempengaruhi faktor-faktor lainnya seperti dorongan orang tua, teman, cita-cita dan lain sebagainya.

\section{ABSTRACT}

The department of Soiology at the 2016-2019 State College of Social Sciences gt its UKT division. The purpose of this artichel is to expresent benefits that show that UKT paymennts are affected by parental income and can thus measure the motives for studentlecture in lowe, moderate, or high levels of study. The method used ia s quantitative approach and the data-collecting technique using an intermediate sampling by the mumber 72 respondents in the population of 345 studentd. The result of this study is a $H_{0}$ received which states that there is no influence betweenparental incentives and a coefficient value of the pearson product moment test -0,94. Factors the affect others of the discovery of data with its significant scale of variabel $X$ (the parents' income) on variable $Y$ (the motivation for collage) of $1 \%$ and the rest of $99 \%$ variable $X$ (the parents' income affect other factors such as the drive of parents, friends, ideals and so on.

(C)2020 LPPM STKIP Persada Khatulistiwa Sintang

\section{PENDAHULUAN}

Tingkat kemiskinan di setiap wilayah Indonesia memiliki tolak ukur yang berbedabeda setiap tahunnya ada yang mengalami kenaikan dan ada yang mengalami penuruan. Salah satu di daerah Jawa Timur khususnya Kota Malang yang ditunjukan pada tabel 1.
Data pada tabel menunjukkan bahwa dari tahun 2011 hingga tahun 2018 kepadatan penduduk mengalami kenaikan, sedangkan untuk pertumbuhan pendudukan menunjukkan penuruan. Terdapat penelitian yang menunjukkan hasil bahwa kepadatan penduduk, tingkat pendidikan, dan tingkat 
pengangguran tidak dapat dipisahkan dari tingkat kemiskinan (Harlik, Amir, \& Hardiani, 2013) sehingga dalam empat variabel ini saling berterkaitan antara satu dengan lainnya.

Tabel.1 Tingkat Kepadatan Penduduk dan Pertumbuhan Penduduk Kota Malang.

\begin{tabular}{|c|c|c|}
\hline \multirow{2}{*}{ Tahun } & \multicolumn{2}{|c|}{ Jumlah } \\
\cline { 2 - 3 } & $\begin{array}{c}\text { Kepadatan } \\
\text { Penduduk }\end{array}$ & $\begin{array}{c}\text { Pertumbuhan } \\
\text { Penduduk }\end{array}$ \\
\hline 2011 & 7.528 & 0.77 \\
\hline 2012 & 7.582 & 0.73 \\
\hline 2013 & 7.639 & 0.75 \\
\hline 2014 & 7.686 & 0.61 \\
\hline 2015 & 7.753 & 0.63 \\
\hline 2016 & 7.781 & 0.60 \\
\hline 2017 & 7.827 & 0.58 \\
\hline 2018 & 7.870 & 0.55 \\
\hline
\end{tabular}

Sumber: Badan Pusat Statistik

Jika dilihat melalui keterkaitan empat variabel yang disebutkan sebelumnya, tingkat kemiskinan di Kota Malang mengalami penurunan dari tahun 2008 (7,22\%) sampai 2018 (4,10\%). Hal ini dapat dibuktikan dengan data pada tabel 2 berikut:

Tabel. 2

Tingkat Kemiskinan Kota Malang

\begin{tabular}{|c|c|}
\hline Tahun & Jumlah Prosentase \\
\hline 2008 & $7.22 \%$ \\
\hline 2009 & $5.58 \%$ \\
\hline 2010 & $5.90 \%$ \\
\hline 2011 & $5.50 \%$ \\
\hline 2012 & $5.19 \%$ \\
\hline 2013 & $4.85 \%$ \\
\hline 2014 & $4.80 \%$ \\
\hline 2015 & $4.60 \%$ \\
\hline 2016 & $4.33 \%$ \\
\hline 2017 & $4.17 \%$ \\
\hline 2018 & $4.10 \%$ \\
\hline
\end{tabular}

Sumber: Badan Pusat Statistik

Dari data di atas menunjukkan bahwasannya kemiskinan di Kota Malang mengalami penurunan disebabkan oleh kesadaran masyarakat akan pentingnya pendidikan. Hal ini dapat dibuktikan pada Utsama (2009) menyatakan bahwasannya penuntasankemiskinan bukan hanya dapat dicapai melalui pengembangan sektor tertentu saja tetapi berbagai sektor penting yang berkenaan dengan kepentingan rakyat banyat, salah satunya yaitu pendidikan serta pengembangan ilmu pengetahuan melalui pendidikan. Maka pendidikan dapat memutus mata rantai kemiskinan dan menghilangkan eksklusi sosial yang kemudan meningkatkan kualitas hidup dan mewujudkan masyarakat yang sejahtera. Maka dari itu, pendidikan yang tinggi menjadi sebuah kebutuhan primer dalam kehidupan masyarakat bukan lagi sebagai kebutuhan tersier. Masyarakat mulai menyadari dengan keadaan di lingkungan sekitar mereka jika pekerjaan yang didapatkan akan sulit jika mengenyam pendidikan yang rendah. Maka dari itu, hal ini menjadi sebuah motivasi bagi setiap individu dengan mengenyam pendidikan yang tidak lagi 12 tahun melainkan hingga mengenyam pendidikan di bidang Akademik atau Universitas.

Di Kota Malang tingkat pendidikan di masyarakat di mulai dari tidak memiliki ijazah hingga pada bidang Akademik atau Universitas. Masyarakat di Kota Malang pada tahun 2018 pendidikan yang ditamatkan paling tertinggi dijenjang SMA sebanyak 33,45\% sedangkan pada jenjang Universtias atau Akademik sejumlah $14,94 \%$ adapun data mengenai tingkat pendidikan masyarakat di Kota Malang tahun 2018 sebagai berikut: 


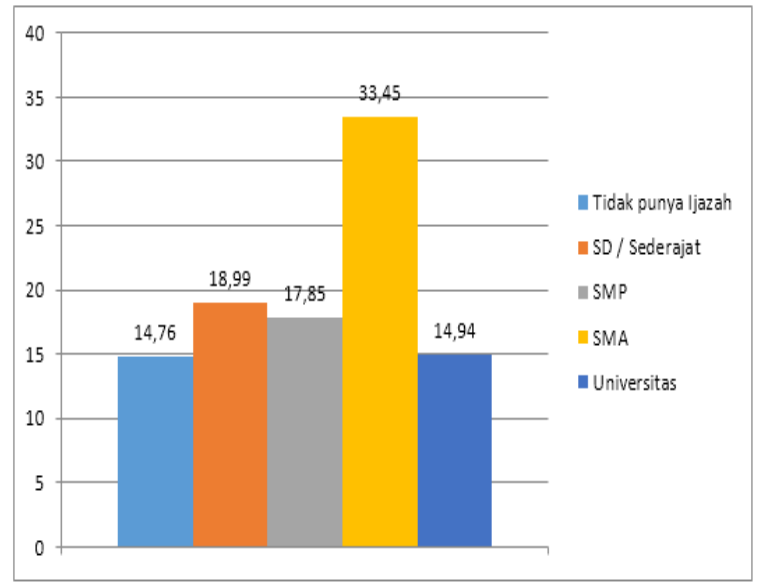

Sumber: Badan Pusat Statistika

Dari data grafik di atas dapat dilihat jika semakin tinggi tingkat pendidikan maka status yang dimiliki individu semakin tinggi atau sebaliknya. Hal ini dapat dibuktikan pada Sarjito (2006) menyatakan bahwa hubungan antara status ekonomi orang tua dengan pilihan jenjang pendidikan dalam studi lanjut siswa oleh orang tua, dapat dilihat adanya kecenderungan orang tua yang status sosial ekonominya tinggi akan memilihkan jenjang pendidikan setingkat Akademik untuk studi lanjut anaknya. Begitupun dengan status ekonomi yang dimiliki oleh individu dalam kehidupan masyarakat menjadi salah satu faktor yang menyebabkan individu memiliki motivasi untuk mengenyam pendidikan yang lebih tinggi yaitu pada pendidikan Akademi atau Universitas.

Dalam memasuki jenjang pendidikan di bidang Akademik atau Universitas jalur seleksinya ada 5 yaitu SNMPT, SBMPTN, BIDIKMISI (Undangan atau Tes), Prestasi dan MANDIRI yang mempengaruhi pada pembayaran UKT mahasiwa setiap bualannya. Hal ini dipengaruhi oleh pendapatan orang tua sehingga terdapat perbedaan pembayaran UKT dengan adanya gelombang dan jumlah tertentu serta menjadi tolak ukur untuk membentuk motivasi kuliah pada mahasiswa dengan melihat pada nilai IPK setiap semesternya. Hal ini dapat ditunjukkan dengan penelitian terdahulu yaitu Eryanto \& Swaramarinda (2013), Dyah (2019), Setiawan, Saputra, \& Nasir (2019), Sumakta (2015), Widayati, (2012).

Menariknya penelitian ini membahas mengenai pengaruh pendapatan orang tua terhadap motivasi kuliah mahasiswa dan masih belum ada kepastian mengenai pengaruh pendapatan orang tua terhadap motivasi kuliah mahasiswa dari penelitian sebelumnya yang fokus terhadap status sosial perekonomian dengan indeks prestasi mahasiswa. Pada penelitian ini, peneliti menguji dengan melihat pembayaran UKT dan prestasi yang diraih sesuai dengan jalur seleksi yang ditempuh ketika masuk perguruan tinggi Universitas Negeri Malang sehingga dapat mengukur motivasi kuliah dari mahasiswa dipengaruhi atau tidak dengan pendapatan orang tua untuk pembayaran UKT setiap semesternya.

Dari latar belakang diatas maka tujuan pada penelitian ini yaitu untuk mengetahui pengaruh pendapatan orang tua terhadap motivasi kuliah pada kalangan Mahasiswa Jurusan Sosiologi Angkatan 2016-2019 Fakultas Ilmu Sosial Univeristas Neegri Malang. Dengan Hipotesi $\mathrm{H}_{1}$ yaiu pendapatan orang tua berpengaruh terhadap motivasi kuliah Mahasiswa Sosiologi angkatan 2016-2019, sedangkan $\mathrm{H}_{0}$ yaitu tidak terdapat pengaruh antara pendapatan orang tua terhadap motivasi kuliah Mahasiswa Sosiologi angkatan 20162019. 


\section{METODE PENELITIAN}

Metode penelitian yang digunakan yaitu metode penelitian kuantitatif yang dilakukan pada situs Fakultas Ilmu Sosial dengan menggunakan kuisoner terhadap sampel 72 orang dari jumlah populasi sebanyak 345 orang Jurusan Sosiologi yang baru terbentuk empat tahun. Kriteria responden yang mengisi kuisioner yaitu seluruh mahasiswa Angkatan 2016-2019 sejumlah 72 mahasiswa yang masuk jalur seleksi SNMPTN, SBMPTN, BIDIKMISI, PRESTASI, dan MANDIRI. Teknik yang digunakan dalam menentukan sampel adalah Accidental Sampling karena tidak memerlukan durasi yang lama dan memberikan kebeasan terhadap peneliti dalam menentukan sampel yang paling membuhi syarat. Sesuai dengan judul penelitian yaitu "Pengaruh Pendapatan Orang Tua Terhadap Motivasi Kuliah Mahasiswa Jurusan Sosiologi Angkatan 2017-2019 Fakultas Ilmu Sosial Universitas Negeri Malang”, maka definisi operasionalnya sebagai berikut:

1. Pendapatan Orang Tua (Variabel X)

2. Motivasi Kuliah (Variabel Y)

3. Indikator dan Konsep, sebagai berikut:

Tabel. 3 Uang Kulih Tunggal Mahasiswa Baru

\begin{tabular}{|c|c|}
\hline Konsep & Indikator \\
\hline $\begin{array}{l}\text { Gaji yang } \\
\text { didapatkan oleh } \\
\text { orang tua sesuai } \\
\text { dengan } \\
\text { pekerjaan yang } \\
\text { dijalani } \\
\text { - UKT yang } \\
\text { dibayarkan } \\
\text { setiap } \\
\text { semesternya }\end{array}$ & $\begin{array}{ll}\text { 1. } & \text { Gaji } \\
\text { 2. } & \text { Pembayaran } \\
\text { UKT }\end{array}$ \\
\hline
\end{tabular}

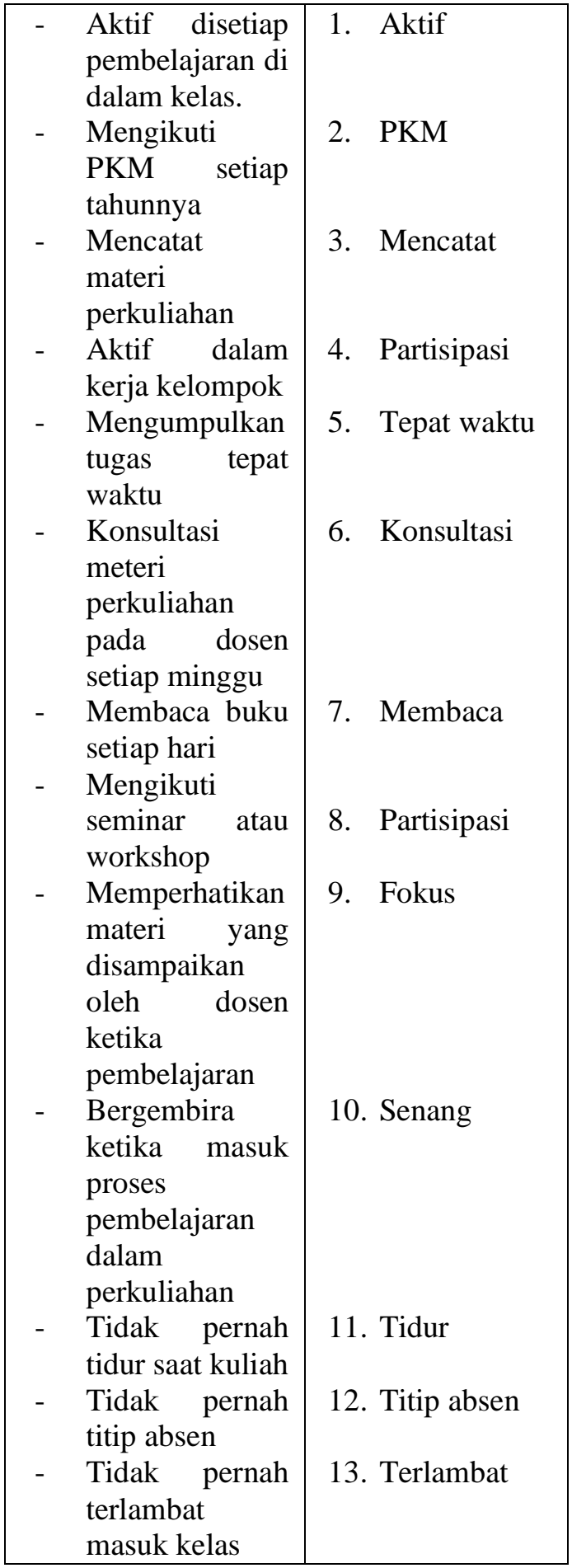

\section{HASIL DAN PEMBAHASAN}

\section{A. Jumlah Mahasiswa Soiologi 2016-2019}

Pada lokasi penelitian, didapatkan responden berjumlah 72 mahasiswa Fakultas Ilmu Sosial dari seluruh populasi sejunlah 345 mahasiswa jurusan sosiologi angkatan 20162019. Data ini didapat dari jumlah keseluruhan 
mahasiswa berdasarkan jalur masuk SBMPTN, SNMPTN, dan Mandiri. Pada angkatan 2016, jumlah mahasiswa yang diterima melalui jalur SBMPTN sebanyak 15 orang, jalur SNMPTN sebanyak 23 orang, serta jalur Mandiri sebanyak 48 orang. Pada angkatan 2017 jumlah mahasiswa yang diterima melalui jalur SBMPTN sebanyak 19 orang, jalur SNMPTN sebanyak 16 orang, dan jalur Mandiri sebanyak 43 orang. Pada angkatan 2018, jumlah mahasiswa yang diterima melalui jalur SBMPTN sebanyak 18 orang, jalur SNMPTN sebanyak 21 orang, dan jalur Mandiri sebanyak 37 orang. Sedangkan pada angkatan 2019, jumlah mahasiswa yang masuk melalui jalur SBMPTN sebanyak 33 orang, jalur SNMPTN sebanyak 18 orang, dan jalur Mandiri sebanyak 54 orang.

\section{B. Kondisi Ekonomi dan Sosial}

Kondisi seseorang juga mempengaruhi kondisi ekonomi dari seseorang. Jika kondisi ekonomi tinggi mereka meraih keinginannya dengan murah. Sedangkan kondisi ekonomi yang kurang mereka, berusaha lebih keras untuk meraih keinginan tersebut (Setianingsih \& others, 2018). Kondisi ekonomi diukur dengan tingkat pendapatan seseorang yang bisa berupa pengahasilan sehari-hari yang berupa gaji atau upah. Bagi orang tua yang menginginkan anaknya untuk memasuki perguruan tinggi, kondisi ekonomi menjadi tolak ukur untuk mereka memasukan anak nya, jika dirasa kondisi ekonomi mereka mencukupi mereka akan tetap berjuang untuk anaknya supaya masuk perguruan tinggi. Dalam Ruang lingkup perguruan tinggi pendapatan orang tua sebagai penentuan pembayaran UKT. Seperti halnya mahasiswa jurusan Sosiologi angkatan tahun 2016-2019 Universitas Negeri Malang, pendapatan orang tua mahasiswa mempengaruhi pembayaran UKT mahasiswa. Rata-rata pendapatan orang tua mahasiswa sebesar Rp.1.000.000-4.000.000 dan bahkan $\geq$ Rp.4.00.0000. Pendapatan tersebut diguanakan untuk menentukan golongan pembayaran UKT mahasiswa. Dan golongan pembayaran UKT pada jurusan sosiologi dibagi menjadi 7 golongan sebagai berikut:

Tabel. 3

UKT Mahasiswa Sosiologi Universitas Ngeri Malang

\begin{tabular}{|c|l|}
\hline Golongan & $\begin{array}{c}\text { Jumlah yang } \\
\text { dibayarkan }\end{array}$ \\
\hline I & Rp.0,- \\
\hline II & Rp.1.000.000 \\
\hline III & Rp.3.500.000 \\
\hline IV & Rp.4.250.000 \\
\hline V & Rp.4.500.000 \\
\hline VI & Rp.5.000.000 \\
\hline VII & Rp.5.500.000 \\
\hline BM & Rp.2.400.000 \\
\hline
\end{tabular}

Sumber: Universitas Negeri Malang

Kondisi social dari seseorang mempengaruhi pola kehidupan dari seseorang tersebut. Kondisi sosial, ekonomi tersebut memiliki peranan terhadap perkembangan seseorang. Dengan adanya perekonomian yang cukup, lingkungan material dalam keluarga lebih luas, seseorang akan mendapatkan kesempatan yang luas. Dengan hal tersebut seseorang yang terlahir dari kondisi sosial yang cukup memadai akan mendapatkan kesempatan untuk mengajar keinginannya. Seperti halnya mahasiswa kondisi sosial tersebut mempengaruhi gaya hidup mahasiswa di perkuliahan. Gaya hidup tersebut didukung 
karena adanya perkenomian keluarga yang memang memadahi.

\section{Pengujian Hipotesis}

\begin{tabular}{|c|c|c|c|}
\hline & & $\begin{array}{l}\text { SUM } \\
\text { Variab } \\
\text { el X }\end{array}$ & $\begin{array}{l}\text { SUM } \\
\text { Variabel } \\
\text { Y }\end{array}$ \\
\hline \multirow{3}{*}{$\begin{array}{c}\text { SUM } \\
\text { Variabel } \\
\mathrm{X}\end{array}$} & $\begin{array}{l}\text { Pearson } \\
\text { Correlation }\end{array}$ & 1 & -.094 \\
\hline & $\begin{array}{l}\text { Sig. (2- } \\
\text { tailed) }\end{array}$ & & .431 \\
\hline & $\mathrm{N}$ & 72 & 72 \\
\hline \multirow{3}{*}{$\begin{array}{l}\text { SUM } \\
\text { Variabel } \\
\mathrm{Y}\end{array}$} & $\begin{array}{l}\text { Pearson } \\
\text { Correlation }\end{array}$ & -.094 & 1 \\
\hline & $\begin{array}{l}\text { Sig. (2- } \\
\text { tailed) }\end{array}$ & .431 & \\
\hline & $\mathrm{N}$ & 72 & 72 \\
\hline
\end{tabular}

Dari tabel diatas dapat diketahui bahwasanya pendapatan orang tua (variabel X) tidak berpengaruh terhadap motivasi kuliah (variabel Y) dengan nilai koefisien korelasi uji pearson product moment $-0,94$. Berarti semakin tinggi tingkat pendapatan orang tua, tidak mempengaruhi motivasi kuliah mahasiswa sosiologi Angkatan 2016-2019. Begitupun sebaliknya, semakin rendah tingkat pendapatan orang tua, tidak mempengaruhi motivasi kuliah mahasiswa sosiologi Angkatan 2016-2019. Maka dapat disimpulkan bahwasanya mahasiswa sosiologi Angkatan 2016-2019 yang berkuliah di Fakultas Ilmu Sosial Universitas Negeri Malang tidak dipengaruhi oleh pendapatan orang tua memalinkan dipengaruhi oleh faktor-faktor lainnya. Taraf signifikansinya variabel $\mathrm{X}$ (pendapatan orang tua) terhadap variabel $\mathrm{Y}$ (motivasi kuliah) sejumlah $1 \%$ dan sisanya 99\% variabel $\mathrm{X}$ (pendapatan orang tua) mempengaruhi factor-faktor lainnya seperti dorongan orang tua, teman, cita-cita dan lain sebagainya.

Dalam tabel diatas dapat dilihat bahwa responden terbagi menjadi tiga kelas berdasarkan pendapatan dan pembayaran UKT (Uang Kuliah Tunggal) yang ada pada variabel $\mathrm{X}$, yakni kelas 2-4 (tinggi) dengan pendapatan dan pembayaran UKT > Rp 4.000.000,00, kelas 5-7 (sedang) dengan pendapatan dan pembayaran UKT Rp 2.000.000,00-Rp 3.000.000,00 dan kelas 8-10 (rendah) dengan pendapatan dan pembayaran UKT Rp 01.000.000,00. Konsep kelas menurut Weber didasarkan atas adanya sekelompok orang yang berada dalam situasi kelas yang sama. Kelas dalam masyarakat merupakan sekelompok orang di dalam situasi ekonomi atau pasar yang sama. Dalam pembagian kelas diatas, responden dikelompokkan berdasarkan pendapatan orang tua dan pembayaran UKT yang telah ditentukan. Kelas-kelas tersebut terbentuk karena adanya situasi ekonomi yang berbeda-beda dari setiap responden sehingga responden terstratifikasi dalam kelas-kelas yang sudah ditentukan mulai dari yang rendah, sedang hingga tinggi. Jalur masuk seleksi perguruan tinggi juga mempengaruhi pembayaran UKT terutama pada jalur Mandiri. Tidak seperti jalur SNMPTN dan SBMPTN yang pembayaran uktnya ditentukan oleh pendapatan orang tua, pembayaran UKT jalur mandiri sudah ditentukan sendiri oleh perguruan tinggi dengan UKT yang tinggi sehingga mahasiswa yang pendapatan orang tuanya rendah tetapi masuk melalui jalur mandiri tetap dikenakan UKT yang tinggi pula sehingga banyak mahasiswa jalur mandiri yang 
masuk dalam kelas tinggi. Tetapi kelas tinggi tidak hanya diisi oleh mahasiswa mandiri saja, tetapi mahasiswa dari jalur SNMPTN DAN SBMPTN yang pendapatan orang tuanya tinggi.

Namun, adanya pembagian kelas berdasarkan pendapatan dan pembayaran UKT dalam mahasiswa sosiologi Angkatan 20162019 ternyata tidak berpengaruh terhadap motivasi kuliah mahasiswa sosiologi Angkatan 2016-2019. Semakin tinggi pendapatan dan pembayaran ukt tidak mempengaruhi motivasi kuliah mahasiswa sosologi angkatan 20162019 dan sebaliknya.

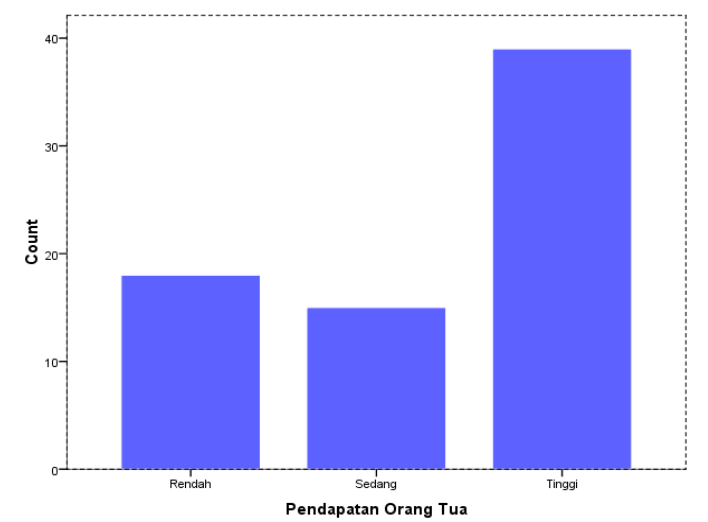

Dari grafik diatas dapat diketahui tingkat partisipasi responden dengan jumlah sebanyak 72 orang yang menjawab pertanyaan mengenai variable $\mathrm{X}$ (pendapatan orang tua) dengan indikator gaji dan pembayaran UKT (uang kuliah tunggal) yaitu partisipasi responden dengan persentase tertinggi pada kelas 8 - 10 dengan pendapatan dan pembayaran UKT Rp.> 4.000.000 sebesar 54,2\% dengan jumlah responden sebanyak 39 orang, sedangkan partisipasi responden dengan persentase sedang pada kelas $5-7$ dengan pendapatan dan pembayaran UKT Rp.2.000.000-3.000.000 sebesar 20,8\% dengan jumlah responden sebanyak 15 orang. Kemudian partisipasi responden dengan persentase terendah pada kelas $2-4$ dengan pendapatan dan pembayaran UKT Rp.0-1.000.000 sebesar 25,0\% dengan jumlah responden sebanyak 18 orang. Sehingga dapat disimpulkan bahwa dominasi pendapatan orang tua mahasiswa Sosiologi angkatan 20162019 tertinggi dengan jumlah Rp. > 4.000.000 sehingga mpengaruhi pembayaran UKT juga tinggi sehingga pendapatan orang tua memberikan pengaruh terhadap pembayaran UKT mahasiswa di Fakultas Ilmu Sosial, Universitas Negeri Malang.

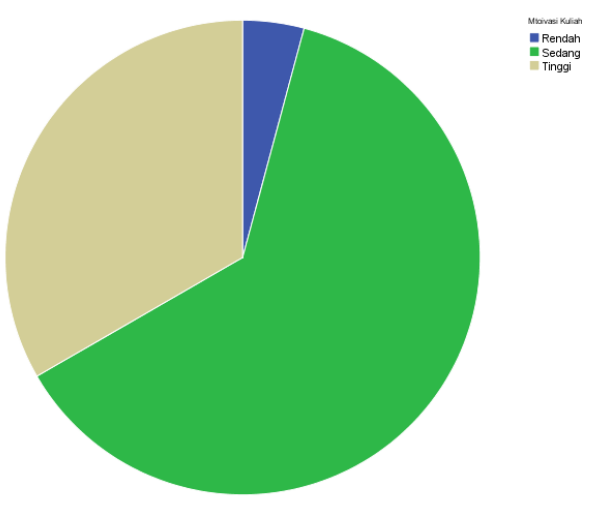

Dari grafik diatas dapat diketahui tingkat partisipasi responden dengan jumlah sebanyak 72 orang yang menjawab pertanyaan mengenai variable Y (motivasi kuliah) dengan indikator aktif, PKM, mencatat, tepat waktu,konsultasi, membaca, partisipasi, fokus, senang, tidur, titip absen, dan terlambat yaitu partisipasi responden sedang dengan persentase tertinggi pada kelas 26 - 38 dengan prosentase sebesar $62,5 \%$ dengan jumlah responden sebanyak 45 orang, selanjutnya partisipasi responden tinggi prosentase sebesar $33,3 \%$ pada kelas $8-25$ dengan jumlah responden sebanyak 24 orang. 
Kemudian partisipasi responden renadah dengan persentase terendah pada kelas $13-25$ dengan jumlah prosetase sebesar $4,2 \%$ dengan jumlah responden sebanyak 3orang. Sehingga dapat disimpulkan bahwa dominasi responden menjawab sedang menunjukkan bahwasannya motivasi kuliah Mahasiswa Sosiologi angkatan 2016-2019 pada ukuran sedang yaitu tidah tinggi dan tidak rendah.

\begin{tabular}{|c|c|c|c|c|c|}
\hline Pernyataan & Tidak Setuju & \begin{tabular}{|c|} 
Cenderung \\
Tidak Setuju \\
\end{tabular} & \begin{tabular}{|c|}
$\begin{array}{c}\text { Cenderung } \\
\text { Setuju }\end{array}$ \\
\end{tabular} & Setuju & Total \\
\hline Nilai Koding & 1 & 2 & 3 & 4 & \\
\hline $\begin{array}{l}\text { Saya selalu aktif setiap pembelajaran di } \\
\text { dalam kelas }\end{array}$ & $\begin{array}{c}1 \\
1,4 \% \\
\end{array}$ & $29,2 \%$ & $50,0 \%$ & $19,4 \%$ & $100 \%$ \\
\hline $\begin{array}{l}\text { Saya selalu mengikut progrram kreatif } \\
\text { mahasiswa (PKM) setiap tahunnya. }\end{array}$ & $25,0 \%$ & $54,2 \%$ & $13,9 \%$ & $69 \%$ & $100 \%$ \\
\hline Saya selalu mencatat materi perkuliahant & $5,6 \%$ & $15,3 \%$ & $50,0 \%$ & $29,2 \%$ & $100 \%$ \\
\hline Saya selalu aktif calam kerja kelompok & $0,0 \%$ & $13,9 \%$ & $38,9 \%$ & $47: 2 \%$ & $100 \%$ \\
\hline $\begin{array}{l}\text { Saya selalu mengumpulkan tugas tepat } \\
\text { wakktu }\end{array}$ & $0,0 \%$ & $6,9 \%$ & $20.8 \%$ & $72,2 \%$ & $100 \%$ \\
\hline $\begin{array}{l}\text { Saya sel alu konsultasi materi perkuliahath } \\
\text { pada Dosen setiap minggul }\end{array}$ & $11,1 \%$ & $59,7 \%$ & $25,0 \%$ & $4,2 \%$ & $100 \%$ \\
\hline Saya selalu membaca buku setiap hari & $19,4 \%$ & $50,0 \%$ & $23,6 \%$ & $6,9 \%$ & $100 \%$ \\
\hline 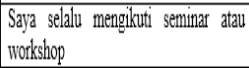 & $0,0 \%$ & $37,5 \%$ & $54,2 \%$ & $83 \%$ & $100 \%$ \\
\hline $\begin{array}{l}\text { Saya selalu memperhatikan materi yang } \\
\text { disampaikan oleh Dosen ketika } \\
\text { pembelajaran }\end{array}$ & $0,0 \%$ & $4,2 \%$ & $54,2 \%$ & $41,7 \%$ & $100 \%$ \\
\hline $\begin{array}{l}\text { Saya selalu bergembira ketika masuk } \\
\text { proses pembelajaran dalam perkuliahan }\end{array}$ & $1,4 \%$ & $22,2 \%$ & $59,7 \%$ & $167 \%$ & $100 \%$ \\
\hline Saya tidak permah tidur saat kuliah & $8,3 \%$ & $23,6 \%$ & $27,8 \%$ & $40,3 \%$ & $100 \%$ \\
\hline Saya tidak pernah Titip Absen & $13,9 \%$ & $36,1 \%$ & $25,0 \%$ & $25,0 \%$ & $100 \%$ \\
\hline Saya tidak pernah terlambat masulk kelas & $13,9 \%$ & $34,7 \%$ & $31,9 \%$ & $19,4 \%$ & $100 \%$ \\
\hline
\end{tabular}

Dari tabel diatas dapat disimpulan bahwsanya mahasiswa sosiolgi angkatan 20162019 yang menjawab pada variable Y (motivasi kuliah) yang trbesar yaitu pada jawaban cenderung tidak setuju sejunlah 387,5\%, disusul pada jawaban cenderung setuju 475,0\%, dan setuju $337,4 \%$ serta pada jawaban tidak stuju dengan prosentase 100,0\%. Sehingga dapat disimpulkan bahwasannya mahasiswa dengan indikator aktif, PKM, mencatat, tepat waktu,konsultasi, membaca, partisipasi, fokus, senang, tidur, titip absen, da terlambat menyatakan cenderunt tidak setuju pada motivasi kuliah belajar mereka setiap harinya.

\section{SIMPULAN}

Dalam penelitian ini disimpulkan bahwasannya tidak adanya korelasi antara motivasi kuliah dengan beban biaya UKT yang dikeluarkan oleh orang tua mahasiswa. Walaupun adanya klasifikasi kelas pembayaran yang dibebankan namun tingkat motivasi dan prestasi yang didapatkan tidak adanya korelasi.bahwasanya pendapatan orang tua (variabel $\mathrm{X}$ ) tidak berpengaruh terhadap motivasi kuliah (variabel $\mathrm{Y}$ ) dengan nilai koefisien korelasi uji pearson product moment - 0,94. Berarti semakin tinggi tingkat pendapatan orang tua, tidak mempengaruhi motivasi kuliah mahasiswa sosiologi Angkatan 2016-2019. disimpulan bahwasannya mahasiswa sosiolgi angkatan 2016-2019 yang menjawab pada variable $\mathrm{Y}$ (motivasi kuliah) yang terbesar yaitu pada jawaban cenderung tidak setuju sejunlah $387,5 \%$, disusul pada jawaban cenderung setuju $475,0 \%$, dan setuju $337,4 \%$ serta pada jawaban tidak setuju dengan prosentase $100,0 \%$. Faktor faktor yang mempengaruhi hal hal yang lain dari penemuan data dengan penghitungan taraf signifikansinya variabel $\mathrm{X}$ (pendapatan orang tua) terhadap variabel Y (motivasi kuliah) sejumlah $1 \%$ dan sisanya 99\% variabel $X$ (pendapatan orang tua) mempengaruhi factor-faktor lainnya seperti dorongan orang tua, teman, cita-cita dan lain sebagainya. Penelitian ini sekaligus merekonstruksi penelitian sebelumnya yang membahas mengenai tingkat pendapatan orang tua berpengaruh terhadap lingkungan 
pendidikan orang tua, indeks prestasi belajar dan aspek sikap mahasiswa, serta pengaruh tingkat pendidikan orang tua terhadap prestasi akademik. Sedangkan pada penelitian ini tidak ada pengaruh pendapatan orang tua terhadap motivas kuliah mahasiswa.

\section{DAFTAR RUJUKAN}

BPS Kota Malang. 2019. Jumlah Kepadatan Penduduk Kota Malang, (online), (https://malangkota.bps.go.id/dynamicta ble/2019/505/14/18/jumlah-pendudukdi-kota-malang-menurut-kecamatandan-jenis-kelamin-2000-2010.html). Di akses pada tangal 2 Oktober 2019.

BPS Kota Malang. 2019. Jumlah Kepadatan Penduduk, Pertumbuhan Penduduk, Rasio Jenis Kelamin, dan Rasio Ketergantungan di Kota Malang, 2011 2020, (online), (https://malangkota.bps.go.id/dynamicta ble/2019/05/08/14/kepadatan-pendudukpertumbuhan-penduduk-rasio-jeniskelamin-dan-rasio-ketergantungan-dikota-malang-2011-2020.html). Di akses pada tanggal 25 November 2019.

Brandan, Y. 2017. Studi Deskriptif Kuantitatif: Resiliensi pada Mahasiswa Perantau Tahun Pertama Skripsi. (online). (repository.usd.ac.id) . Diakses 03 oktober 2019.

Dyah, D. A. 2019. Pengaruh Pendapatan Orang Tua dan Lingkungan Sosial Terhadap Minat Melanjutkan Pendidikan Program Magister pada Mahasiwa Fakultas Ekonomi Universitas Negeri Yogjakarta Tahun Angkatan 2014-2015. Jurnal Pendidikan dan Ekonomi, 8(2), 158-165.

Eryanto, H., \& Swaramarinda, D. R. 2013. Pengaruh Modal Budaya, Tingkat Pendidikan Orang Tua dan Tingkat Pendapatan Orang Tua Terhadap Prestasi Akademik Pada Mahasiswa Fakultas Ekonomi Universitas Negeri Jakarta. Jurnal Pendidikan Ekonomi Dan Bisnis (JPEB), 1(1), 39-61.
Harlik, H., Amir, A., \& Hardiani, H. 2013. Faktor-Faktor yang Mempengaruhi Kemiskinan dan Pengangguran di Kota Jambi. Jurnal Perspektif Pembiayaan dan Pembangunan Daerah, 1(2), 109120.

Maksum, Ali. 2013. Sosiologi Pendidikan. (online).

(https://digilib.uinsby.ac.id/20248/1/Sos iologi\%20Pendidikan.pdf)

. Diakses pada tanggal 2 Oktober 2019.

Moeleong, L. 2016. Metodologi Penelitian Kualitatif. Bandung: PT Remaja Rosdakarya.

Ritzer, George. 2012. Teori Sosiologi Klasik Sampai Perkembangan Terakhir Postmodern. Yogjakarta: Pustaka Pelajar.

Sarjito, L. 2006. Hubungan Antara Status Sosial Ekonomi Orang Tua dengan Pilihan Jenjang Pendidikan dalam Studi Lanjut Siswa. Skripsi

Setianingsih, S. A., \& others. 2018. Pengaruh Status Sosial Ekonomi Orang Tua dan Gaya Hidup Terhadap Perilaku Konsumtif Mahasiswa (Studi Kasus Mahasiswa Fakultas Ekonomi dan Bisnis Islam IAIN Purwokerto) (PhD Thesis). IAIN Purwokerto.

Setiawan, D., Saputra, H. D., \& Nasir, M. 2019. Pengaruh Status Sosial Ekonomi dan Lingkungan Kampus Terhadap IPK Mahasiswa. INVOTEK: Jurnal Inovasi Vokasional dan Teknologi, 19(1), 6774.

Sumakta, I. A. 2015. Pengaruh Prestasi Belajar, Pendapatan Orang Tua, Ekspektasi Kerja terhadap Minat Melanjutkan Studi ke S2 pada Mahasiswa Pendidikan Ekonomi FE UNY. Skripsi. Universitas Negeri Yogyakarta.

Ustama, D D. 2009. Peranan Pendidikan dalam Pengentasan Kemiskinan. Jurnal Ilmu Administrasi dan Kebijakan Publik. DIALOGUE 
Widayati, I. 2012. Pengaruh Status Sosial Ekonomi Orang Tua, Pendidikan Pengelolaan Keuangan Keluarga, dan Pembelajaran di Perguruan Tinggi Terhadap Literasi Finansial Mahasiswa Fakultas Ekonomi dan Bisnis Universitas Brawijaya.(Tesis). DISERTASI dan TESIS Program Pascasarjana UM. 